\title{
Spatially distributed runoff at the grounding line of a large Greenlandic tidewater glacier inferred from plume modelling
}

\author{
DONALD SLATER, ${ }^{1}$ PETER NIENOW, ${ }^{1}$ ANDREW SOLE, ${ }^{2}$ TOM COWTON, ${ }^{1,3}$ \\ RUTH MOTTRAM, ${ }^{4}$ PETER LANGEN, ${ }^{4}$ DOUGLAS MAIR ${ }^{5}$
}

\author{
${ }^{1}$ School of Geosciences, University of Edinburgh, Edinburgh, UK \\ ${ }^{2}$ Department of Geography, University of Sheffield, Sheffield, UK \\ ${ }^{3}$ Department of Geography and Sustainable Development, University of St Andrews, St Andrews, UK \\ ${ }^{4}$ Danish Meteorological Institute, Copenhagen, Denmark \\ ${ }^{5}$ School of Environmental Sciences, University of Liverpool, Liverpool, UK \\ Correspondence: Donald Slater <d.slater@ed.ac.uk>
}

\begin{abstract}
Understanding the drivers of recent change at Greenlandic tidewater glaciers is of great importance if we are to predict how these glaciers will respond to climatic warming. A poorly constrained component of tidewater glacier processes is the near-terminus subglacial hydrology. Here we present a novel method for constraining near-terminus subglacial hydrology with application to marine-terminating Kangiata Nunata Sermia in South-west Greenland. By simulating proglacial plume dynamics using buoyant plume theory and a general circulation model, we assess the critical subglacial discharge, if delivered through a single compact channel, required to generate a plume that reaches the fjord surface. We then compare catchment runoff to a time series of plume visibility acquired from a time-lapse camera. We identify extended periods throughout the 2009 melt season where catchment runoff significantly exceeds the discharge required for a plume to reach the fjord surface, yet we observe no plume. We attribute these observations to spatial spreading of runoff across the grounding line. Persistent distributed drainage near the terminus would lead to more spatially homogeneous submarine melting and may promote more rapid basal sliding during warmer summers, potentially providing a mechanism independent of ocean forcing for increases in atmospheric temperature to drive tidewater glacier acceleration.
\end{abstract}

KEYWORDS: glacier hydrology, ice/ocean interactions, subglacial processes

\section{INTRODUCTION}

Mass loss from the Greenland ice sheet is accelerating, driven both by decreasing surface mass balance and increased ice discharge into the ocean from tidewater glaciers (van den Broeke and others, 2009). From 2000 to 2005, ice discharge accounted for more than half of the total mass loss during a period of pronounced acceleration, thinning and retreat of Greenlandic tidewater glaciers (Pritchard and others, 2009; Moon and others, 2012; Enderlin and others, 2014). The widespread nature of this behaviour is indicative of a common climatic forcing, and although substantial ocean warming has been widely implicated as a driver of change at tidewater glaciers (e.g. Holland and others, 2008; Christoffersen and others, 2011), process understanding of how a warming ocean perturbs a tidewater glacier remains at an early stage. Attribution of a mechanism for observed tidewater glacier change is confounded by a broadly coincident increase in ice-sheet surface melting (Fettweis and others, 2011), which may also impact tidewater glacier dynamics. Due to our incomplete understanding of key tidewater glacier processes, we are currently limited in our ability to make projections of tidewater glacier dynamics and ultimately to quantify their future contribution to global sea level (Straneo and Heimbach, 2013).

One process through which the ocean interacts with tidewater glacier termini is submarine melting. Submarine melting is thought to be promoted by the emergence of subglacial discharge at the grounding line, forming plumes which rise buoyantly up the calving front (Motyka and others, 2003, 2013; Jenkins, 2011; Straneo and Cenedese, 2015). These plumes both increase the transfer of heat from the ocean to the ice and help to draw warm water towards the calving front by setting up an exchange flow in the proglacial fjord (Straneo and others, 2010; Cowton and others, 2015). Progress has recently been made in modelling submarine melting, with the magnitude of subglacial discharge, fjord water properties, grounding line depth and near-terminus subglacial hydrology identified as key controls on the rate and distribution of submarine melting (Jenkins, 2011; Sciascia and others, 2013; Xu and others, 2013; Kimura and others, 2014; Slater others, 2015, 2016; Carroll and others, 2016). Of these four controls, near-terminus subglacial hydrology is perhaps the most poorly constrained. Channelised subglacial drainage leads to rapid but localised melting of a calving front, while distributed subglacial drainage leads to slower and more homogeneous melting that results in higher total submarine melt rate (Slater and others, 2015). It is therefore important to constrain near-terminus subglacial hydrology if we are to understand the role of submarine melting in tidewater glacier dynamics.

A further motivation to study subglacial hydrology at tidewater glaciers comes from its role in modulating basal water pressure and ice velocity. The relationship between subglacial hydrology and ice velocity has long been studied at alpine glaciers (Iken and Bindschadler, 1986) and more recently at land-terminating glaciers in Greenland (e.g. 
Bartholomew and others, 2010). These land-terminating systems typically show transient increases in ice velocity during periods of rapid increase in surface melting (Bartholomew and others, 2010). Once runoff is stable or decreasing, typically in late summer, ice velocity may fall to levels below pre-melt season values due to the development of efficient subglacial channels, which act to reduce water pressure over a significant area of the bed (Schoof, 2010; Cowton and others, 2013; Hewitt, 2013). At present, however, it remains unclear to what extent conclusions from subglacial hydrology at land-terminating glaciers may be transferred to tidewater glaciers.

A number of studies have noted a seasonal evolution of ice velocity at some tidewater glaciers akin to that of land-terminating glaciers, suggesting that the hydrological systems may behave similarly (Howat and others, 2010; Sole and others, 2011; Moon and others, 2014). These studies do not however extend all the way to the glacier terminus and there are indications from other studies that the hydrological systems may behave quite differently. For example, drilling of boreholes to the bed of calving glaciers (Meier and others, 1994; Sugiyama and others, 2011) has shown water pressure can be consistently close to ice overburden. In particular, the results of Sugiyama and others (2011) from Glacier Perito Moreno in Patagonia suggest a lack of evolution towards more efficient subglacial hydrology through the summer, demonstrated by a strong positive correlation between air temperature and ice velocity, and providing a direct link between atmospheric warming and glacier acceleration.

Study of near-terminus subglacial hydrology in the field is however challenging; the terminus region of these fastflowing glaciers is invariably highly crevassed and it is currently impossible to monitor proglacial discharge as this water flows directly into the fjord at the glacier grounding line. Some insight can be gained with measurements made from the proglacial fjord; side scan sonar can map the morphology of the calving front (Fried and others, 2015; Rignot and others, 2015), while detailed knowledge of ocean properties close to the terminus gives information on locations of subglacial discharge (Stevens and others, 2016). These studies confirm the existence of focused subglacial discharge at the grounding line, but cannot draw conclusions on the emergence of smaller volumes of discharge elsewhere. Furthermore, the data presented in these studies have limited temporal coverage and may be difficult to obtain at glaciers with significant ice mélange.

In this paper, we present a method for assessing near-terminus subglacial hydrology with application to Kangiata Nunata Sermia (KNS), a large tidewater glacier in Southwest Greenland. We obtain time series of total catchment runoff and plume visibility at the fjord surface and simulate proglacial plume dynamics using both a simple plume model and the MIT general circulation model (MITgcm). By comparing modelled to observed plume visibility, we attempt to quantify the spatial distribution of subglacial discharge emerging at the grounding line through the 2009 melt season. Two very recent studies have taken a similar approach. Bartholomaus and others (2016) obtained plume visibility from satellite imagery at $\sim 1.5$ week temporal resolution for three glaciers in West Greenland and compared with a simple plume model, but did not consider the effect of subglacial hydrology on plume visibility in any detail. Schild and others (2016) present a 5 year time series of plume visibility and runoff for Rink Glacier, West
Greenland, but did not include consideration of plume dynamics. In our study, we combine a time series of plume visibility at hourly resolution with a detailed consideration of plume dynamics, enabling a degree of quantification of near-terminus subglacial hydrology. We discuss the extent to which the subglacial hydrology near the terminus of a fast-flowing tidewater glacier may differ from that further inland or at land-terminating glaciers, and consider the implications of our findings for submarine melting and ice dynamics.

\section{STUDY AREA}

KNS is the largest tidewater glacier in South-west Greenland (Fig. 1), draining $\sim 2 \%$ of the Greenland ice sheet (Sole and others, 2011). At the calving front, which is $4.5 \mathrm{~km}$ wide and grounded $\sim 250 \mathrm{~m}$ below sea level, ice velocity reaches $20 \mathrm{~m} \mathrm{~d}^{-1}$ (Joughin and others, 2010; Mortensen and others, 2011). Lea and others (2014) have reconstructed the dynamics and terminus position of KNS since 1859, showing that the glacier has retreated nearly $10 \mathrm{~km}$ since 1921 with only short periods of readvance. Retreat was particularly rapid in the late 1940s when the termini of KNS and the adjacent Akugdlerssûp Sermia (AS) separated. Since 2000, KNS has undergone acceleration and thinning, but only modest retreat averaging $\sim 100 \mathrm{~m} \mathrm{a}^{-1}$ (Rignot and Kanagaratnam, 2006; Thomas and others, 2009; Lea and others, 2014). Previous hydrological study has inferred that seasonal evolution of ice velocity $>35 \mathrm{~km}$ inland from the

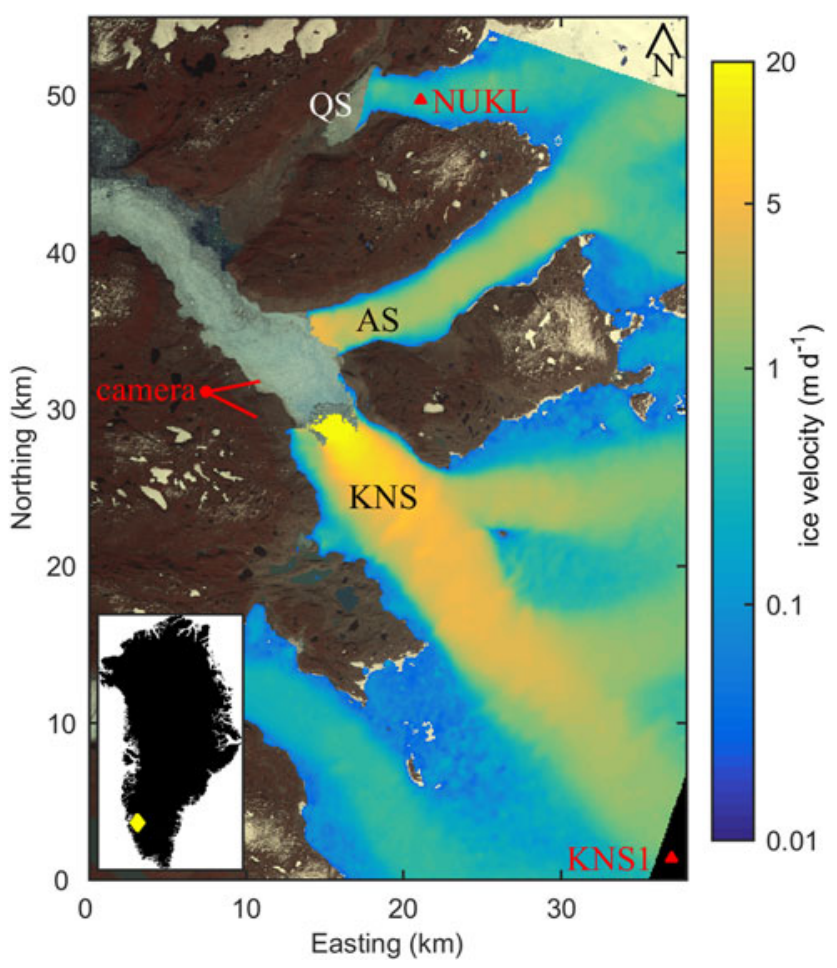

Fig. 1. Overview plot of study site with KNS, QS and AS labelled. Background is an ASTER image from 22 June 2009. Colour overlay shows ice velocities calculated in the interval 21 August 2009 to 1 September 2009 from the NSIDC MEaSUREs dataset (Joughin and others, 2010, 2011). Note the logarithmic velocity colour scale. Also shown is the location and approximate field of view of the time-lapse camera, the GPS station KNS1 and the PROMICE station NUKL. Bottom left inset shows location in South-west Greenland. 
calving front is controlled by surface melt-induced development of the subglacial drainage system, in a manner similar to land-terminating margins (Sole and others, 2011). More recent work shows late summer deceleration in ice velocity that extends to within a few kilometres of the calving front, presumably induced by the evolution of the subglacial drainage system to an efficient state (Ahlstrom and others, 2013; Moon and others, 2014; Fahnestock and others, 2015).

KNS flows into the Godthåbsfjord system, the oceanography of which has received extensive study (Mortensen and others, 2011, 2013, 2014; Kjeldsen and others, 2014; Bendtsen and others, 2015). During the summer of 2009, which forms the focus of this study, the inner part of this fjord ( $\sim 40 \mathrm{~km}$ closest to KNS) was characterised by a warm $\left(\sim 1-2^{\circ} \mathrm{C}\right)$ water mass at depths $>90 \mathrm{~m}$, resulting from tidally-induced downward mixing of heat in the outer fjord and periodic inflows of dense coastal water (Mortensen and others, 2013). At $<90 \mathrm{~m}$ depth the water became cooler and fresher due to an outflowing mixture of subglacial discharge and ambient fjord water, while the fjord surface ( $<10 \mathrm{~m}$ depth) was characterised by a very fresh layer resulting from terrestrial freshwater runoff and iceberg melting (Mortensen and others, 2013). It should be noted however that these characteristics have been inferred from ocean data taken $>20 \mathrm{~km}$ from the calving front as dense ice mélange often prohibits detailed study close to the KNS terminus.

\section{METHODS}

\subsection{Controls on plume visibility}

This paper utilises the relationship between the visibility of a plume on the fjord surface and the magnitude of subglacial discharge initiating the plume. This relationship has received extensive study at laboratory scales (e.g. Morton and others, 1956), in theoretical studies (e.g. Slater and others, 2016) and in numerical modelling (e.g. Carroll and others, 2015). Each of these approaches suggests the following qualitative description of plume dynamics.

Plumes at the margins of tidewater glaciers are initiated by subglacial discharge emerging from the grounding line and rising buoyantly to form a plume. As the plume rises, turbulent entrainment at the plume boundary dilutes the plume with salty ocean water, decreasing the density difference between the plume and fjord (Morton and others, 1956). As a result, there may come a depth where the plume and ambient water density are equal, termed the level of neutral buoyancy. Due to vertical momentum, the plume can continue rising past this depth. However, above the level of neutral buoyancy the plume is negatively buoyant, and thus the plume slows, reaches a maximum height, then dives back downwards as it flows away from the glacier (Carroll and others, 2015). Alternatively, the plume may reach the fjord surface before reaching neutral buoyancy or running out of vertical momentum (Slater and others, 2016).

The level of neutral buoyancy and maximum height reached depend on the fjord stratification and magnitude of subglacial discharge (Carroll and others, 2015; Slater and others, 2016). For small subglacial discharges, the resulting plume mixes rapidly with ambient fjord water and carries little momentum. The plume will thus reach neutral buoyancy and maximum height at some depth below the fjord surface. As subglacial discharge is increased, the resulting plume takes longer to dilute, preserving its positive buoyancy and shifting the level of neutral buoyancy and maximum height to shallower depths. At some critical subglacial discharge the plume has sufficient buoyancy to reach the fjord surface.

If we have a record of when a plume is visible at the fjord surface adjacent to a tidewater glacier, then by considering fjord stratification and plume dynamics we may gain information about the subglacial discharge resulting in the presence or absence of a plume. In addition, if we know the total catchment runoff reaching the terminus, then constraints can be placed on the configuration of the subglacial drainage system near the terminus.

\subsection{Catchment runoff}

We estimate KNS catchment runoff through the summer of 2009 using two standard methods. In the first, we use a classic positive degree day sum (PDD) approach (Hock, 2003). We use air temperatures and surface ablation recorded at four sites, KNS1-4, sited in the catchment at 1282-1840 m elevation (Fig. 1, details in Sole and others (2011)) to obtain degree day factors for snow $\left(d d f_{\mathrm{s}}\right)$ and for ice $\left(d d f_{\mathrm{i}}\right)$. We delineated the KNS catchment using topographic data from the BedMachine dataset (Morlighem and others, 2014, 2015; Howat and others, 2014) and a standard hydropotential analysis (Shreve, 1972). In order to run the PDD model, we need to extrapolate snow depth, degree day factors and air temperature to the full catchment. We take the simplest approach of using constant snow depth and degree day factors over the full catchment. These constant values are set at the mean values over the four GPS sites, giving a snow depth of $33 \mathrm{~cm}, d d f_{\mathrm{s}}=4.5 \mathrm{~mm}$ $\mathrm{d}^{-1{ }^{\circ}} \mathrm{C}^{-1}$ and $d d f_{\mathrm{i}}=11.9 \mathrm{~mm} \mathrm{~d}^{-1{ }^{\circ}} \mathrm{C}^{-1}$. These degree day factors are comparable to or slightly higher than those obtained at nearby Qamanârssûp sermia (QS) (Fig. 1) at an elevation of $790 \mathrm{~m}$ (Braithwaite, 1995). To obtain air temperature over the full catchment we assume a linear relationship between elevation and air temperature. This linear relationship is calculated at each PDD time step using data from KNS1-4, and additional data from PROMICE station NUKL (Ahlstrom and others, 2008) located nearby at an elevation of $550 \mathrm{~m}$ (Fig. 1).

The PDD approach is simplistic in many ways (e.g. it does not take account of refreezing of meltwater in the snowpack) but compares well with the more sophisticated regional climate model described below. One point which is particularly relevant to this study is that the PDD model outputs an estimate of surface ablation, which is related to but not equivalent to runoff of subglacial discharge at the grounding line. Meltwater from surface ablation may percolate through snow and/or enter a supraglacial drainage system before reaching the glacier bed through a moulin or crevasse. Meltwater may also be stored in surface lakes before drainage to the bed. Runoff resulting from surface lake drainage at KNS has been estimated using MODIS imagery by Sole and others (2011). They estimate that the largest drainage event occurs on day 201 and contributes $70 \mathrm{~m}^{3} \mathrm{~s}^{-1}$. As such, the contribution to runoff from lake drainage is expected to be significantly smaller than surface melting, and we do not make further explicit consideration of lake drainage.

Once in the subglacial drainage system, travel time through the system may vary significantly depending on the 
state of the hydraulic system (Fountain and Walder, 1998). The cumulative effect of all of these processes will be to delay meltwater from production to entering the fjord. There may also be seasonal variation in this delay, with typically faster transit times in late summer (Campbell and others, 2006; Cowton and others, 2013). We attempt to take account of these processes by using transit velocities to delay runoff. We consider end-member transit velocities (Cowton and others, 2013) of $0.05 \mathrm{~m} \mathrm{~s}^{-1}$ ('delayed') and 1 $\mathrm{m} \mathrm{s}^{-1}$ ('rapid'). Thus, meltwater produced $30 \mathrm{~km}$ from the terminus would enter the fjord $\sim 1$ week later in the 'delayed' scenario. It will be seen that our broad conclusions are not sensitive to the choice of transit velocity.

Our second estimate of runoff comes from the regional climate model HIRHAM5, applied to Greenland at $5 \mathrm{~km}$ resolution. The model has been described in detail in Langen and others (2015); HIRHAM5 combines the HIRLAM weather forecasting model (Eorola, 2006), physics schemes derived from the ECHAM5 general circulation model (Roeckner and others, 2003), and a dynamic snow/ice surface scheme. The model has demonstrated ability to accurately simulate runoff in the Godthåbsfjord region (Langen and others, 2015). An important point for this study is that surface melt from the model runs off with a timescale depending on surface slope as in the regional climate model MAR (Zuo and Oerlemans, 1996; Lefebre and others, 2003).

\subsection{Plume visibility}

A time series of plume visibility was created with images from a time-lapse camera. The camera was located on a ridge a few kilometres northwest of the calving front (Fig. 1) and captured an image every hour from 11 May 2009 (day 131) until 7 September 2009 (day 250). We manually classified these images into four states (Fig. 2). Images showing the presence of an ice tongue were assigned a value -1 (Fig. 2a). Images without an ice tongue but with no surface expression of a plume were assigned a value 0 (Fig. 2b). Images showing the presence of a plume at the fjord surface were assigned a value of respectively 1 or 2 depending on whether the surface expression of the plume was limited to within a few hundred metres of the calving front (Fig. 2c) or whether the plume flowed down-fjord at the surface for a number of kilometres (Fig. 2d). We are confident that the open water signatures which we interpret as plumes are not caused by calving or wind events as the open water is visibly turbid (e.g. Figs 2c, d), indicating a subglacial origin. The result is a time series of plume visibility at hourly resolution through the summer of 2009. Data gaps result from camera malfunction or when bad weather obscured the calving front.

\subsection{Plume dynamics}

Plume dynamics are also modelled using two methods. Both have been widely applied to simulate plumes adjacent to glaciers and have been described in detail elsewhere (Jenkins, 2011; Carroll and others, 2015; Slater and others, 2016). Here we provide only a brief overview.

The first model we employ is buoyant plume theory (BPT) (Morton and others, 1956). BPT describes the evolution of a plume as it rises by solving conservation equations for volume, momentum and buoyancy. Turbulent mixing of the plume with fjord water is incorporated by assuming entrainment into the plume is proportional to the plume velocity (Morton and others, 1956). The model includes the feedback of submarine melting on plume buoyancy and frictional drag at the ice-ocean interface. We consider two plume geometries; a half-conical shape which we suggest is appropriate for plumes arising from narrow subglacial channels (i.e. point sources), and a wedge shape which we suggest is appropriate for plumes arising from very wide channels or diffuse subglacial discharge (i.e. line sources). Details of the model for the two geometries can be found in Slater and others (2016).

Although BPT captures much of the essential dynamics, it does not include any consideration of the fjord surface and does not describe what happens to water from the plume after the plume has reached its maximum height. To address these shortcomings and to provide a visual comparison of model and observation, we model the point source plumes in a high-resolution non-hydrostatic configuration of the MITgcm (Marshall and others, 1997a, b). Our aim is to accurately simulate near-ice plume dynamics rather than the full fjord circulation, thus the model domain is an idealised version of the proglacial fjord. We use a uniform fjord depth of $250 \mathrm{~m}$, a width of $1 \mathrm{~km}$ and a length of $26 \mathrm{~km}$. The domain is designed to be sufficiently wide and long that the boundaries do not affect plume dynamics. We do not expect that the idealised nature of our model domain, and in particular the lack of detailed near-glacier bathymetry, significantly affects the plume dynamics, which are the focus of this study. In the near-ice region, we employ an isotropic model resolution of $5 \mathrm{~m}$, with subgrid-scale mixing parameters calibrated using BPT. A detailed description of the model configuration can be found in Slater and others (2015).

Fjord stratification in both BPT and MITgcm is set using a temperature and salinity profile taken in the fjord $\sim 35 \mathrm{~km}$ from KNS on 5 August 2009 (Figs 3c, d, Mortensen and others (2013)). We model plumes resulting from point source discharges of 1-500 $\mathrm{m}^{3} \mathrm{~s}^{-1}$ and line source discharge per unit width from 0.01 to $2 \mathrm{~m}^{2} \mathrm{~s}^{-1}$. We observe changes in plume dynamics with a focus on the surface expression of the plume.

Finally, additional data considered in this study include ice velocity from KNS1 (Fig. 1, Sole and others (2011)), which provides information on channelisation of subglacial hydrology higher up in the catchment, and ice velocities over the wider glacier (Fig. 1) from the NSIDC MEaSUREs dataset (Joughin and others, 2010, 2011). Unfortunately, subglacial topography is poorly constrained near to the terminus of KNS (Morlighem and others, 2014), preventing the meaningful modelling of drainage pathways for comparison with the observed plume locations (e.g. Fried and others, 2015).

\section{RESULTS}

\subsection{Plume modelling}

Results from BPT for point sources of subglacial discharge from 1 to $500 \mathrm{~m}^{3} \mathrm{~s}^{-1}$ are shown in Figure 3. For the smallest discharge considered $-1 \mathrm{~m}^{3} \mathrm{~s}^{-1}$ - the plume mixes rapidly, with plume salinity close to the ambient fjord value within $50 \mathrm{~m}$ above the grounding line. However, the fjord is very weakly stratified below $50 \mathrm{~m}$ depth, and therefore despite this plume being relatively weak, it still reaches to within $50 \mathrm{~m}$ of the fjord surface (Fig. 3b). As discharge is increased, plume width and velocity increase, plume temperature and 

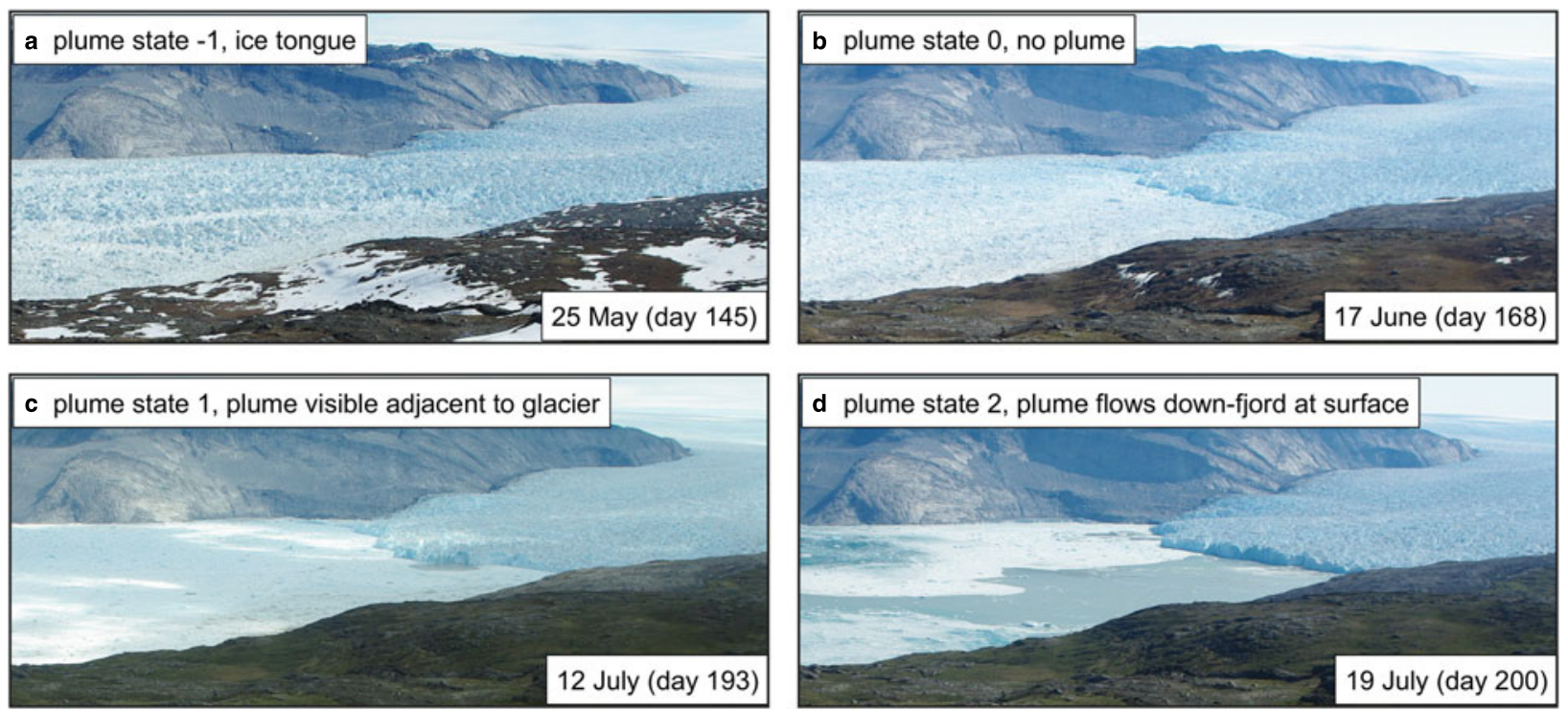

Fig. 2. Illustrations of plume state classification. (a) Plume state $=-1$, ice tongue present. (b) Plume state $=0$, no ice tongue and no surface expression of a plume. (c) Plume state $=1$, plume visible adjacent to glacier terminus but is contained within a few hundred metres of the terminus. (d) Plume state $=2$, plume visible and flows down-fjord at surface for a number of kilometres.
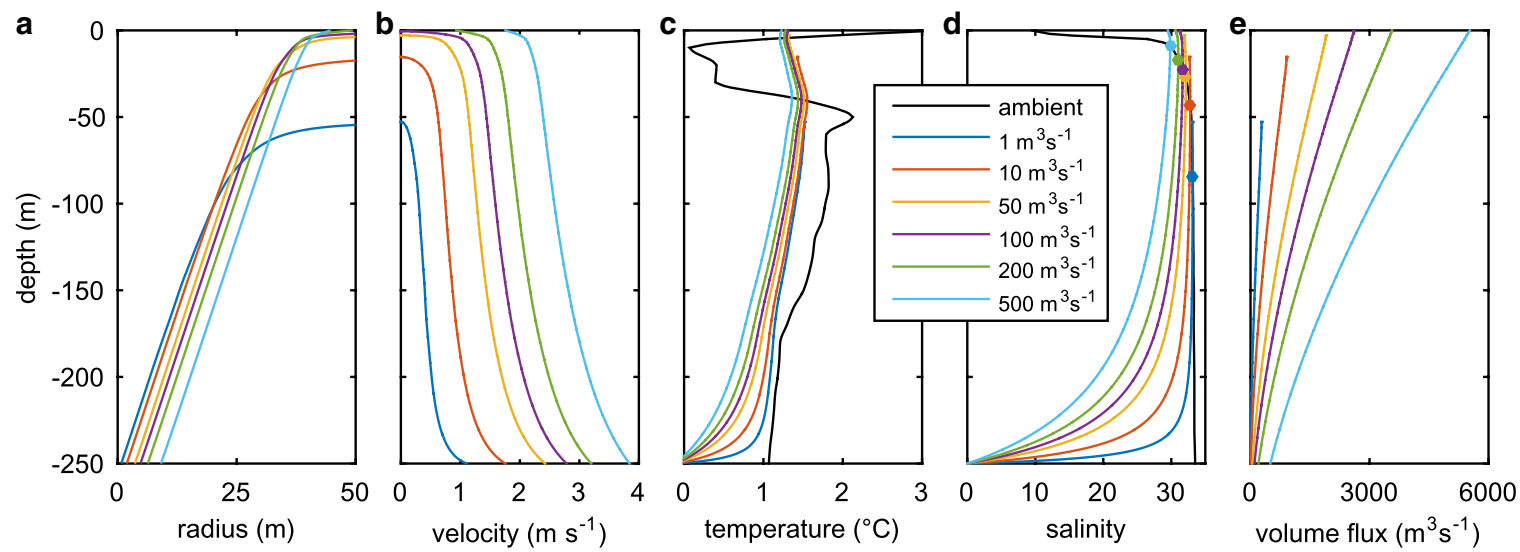

Fig. 3. Plume modelling with BPT assuming a narrow subglacial channel (point source), for discharges from 1 to $500 \mathrm{~m}^{3} \mathrm{~s}^{-1}$. Grounding line is located at $-250 \mathrm{~m}$ and the fjord surface at $0 \mathrm{~m}$. Panel (a) shows plume radius, (b) plume velocity, (c) plume temperature, (d) plume salinity and (e) plume volume flux. Ambient fjord temperature and salinity are shown in black in (c) and (d). Salinities are expressed here and throughout this paper using the practical salinity scale. Filled symbols in (d) indicate the height at which the plume salinity exceeds the ambient salinity. Results suggest a plume initiated by a discharge of $1 \mathrm{~m}^{3} \mathrm{~s}^{-1}$ will reach a maximum height $\sim 50 \mathrm{~m}$ below the fjord surface, while plumes resulting from discharges upwards of $50 \mathrm{~m}^{3} \mathrm{~s}^{-1}$ reach - or effectively reach - the fjord surface.

salinity approach ambient values more slowly and the plume reaches closer to the surface. The extremely fresh surface layer, with salinity as low as 10 (Fig. 3d), causes plumes to slow as they approach the fjord surface (Fig. 3b).

Of particular interest to this study is the critical subglacial discharge at which the resulting plume will be visible at the fjord surface. In Figure 3, discharges of $100 \mathrm{~m}^{3} \mathrm{~s}^{-1}$ or greater reach the fjord surface. However, BPT does not provide any information about the fate of water within the plume after the plume reaches either the surface or its maximum height. For example, the plume resulting from a discharge of $50 \mathrm{~m}^{3} \mathrm{~s}^{-1}$ reaches within $5 \mathrm{~m}$ of the fjord surface and carries a volume flux of $2000 \mathrm{~m}^{3} \mathrm{~s}^{-1}$ at its maximum height (Figs 3b, e). This volume flux must flow down-fjord away from the glacier in a layer of finite thickness; therefore, it is possible that the plume resulting from a discharge of
$50 \mathrm{~m}^{3} \mathrm{~s}^{-1}$ would indeed be visible at the fjord surface. To consider this possibility we turn to our modelling in $\mathrm{MITgCm}$.

Results from the point source plume modelling in MITgcm are shown in Figure 4. The plots show side-view crosssections through the centre of the modelled plumes for discharges from 5 to $500 \mathrm{~m}^{3} \mathrm{~s}^{-1}$. The smallest discharge modelled $-5 \mathrm{~m}^{3} \mathrm{~s}^{-1}$ (Fig. 4a) - results in a plume which rises to within $\sim 20 \mathrm{~m}$ of the fjord surface. The majority of plume water finds neutral buoyancy at $\sim 50 \mathrm{~m}$ depth and flows down-fjord at velocities up to $0.1 \mathrm{~m} \mathrm{~s}^{-1}$. There are slow compensatory inflows of a few $\mathrm{cm} \mathrm{s}^{-1}$ (below $100 \mathrm{~m}$ depth and at the surface). The plume induces some disturbance at the surface; however, water velocities here are very small $\left(<0.05 \mathrm{~m} \mathrm{~s}^{-1}\right)$ and if there is ice mélange at the surface we suggest this plume would be unlikely to show any surface expression (cf. Fig. 2b). 

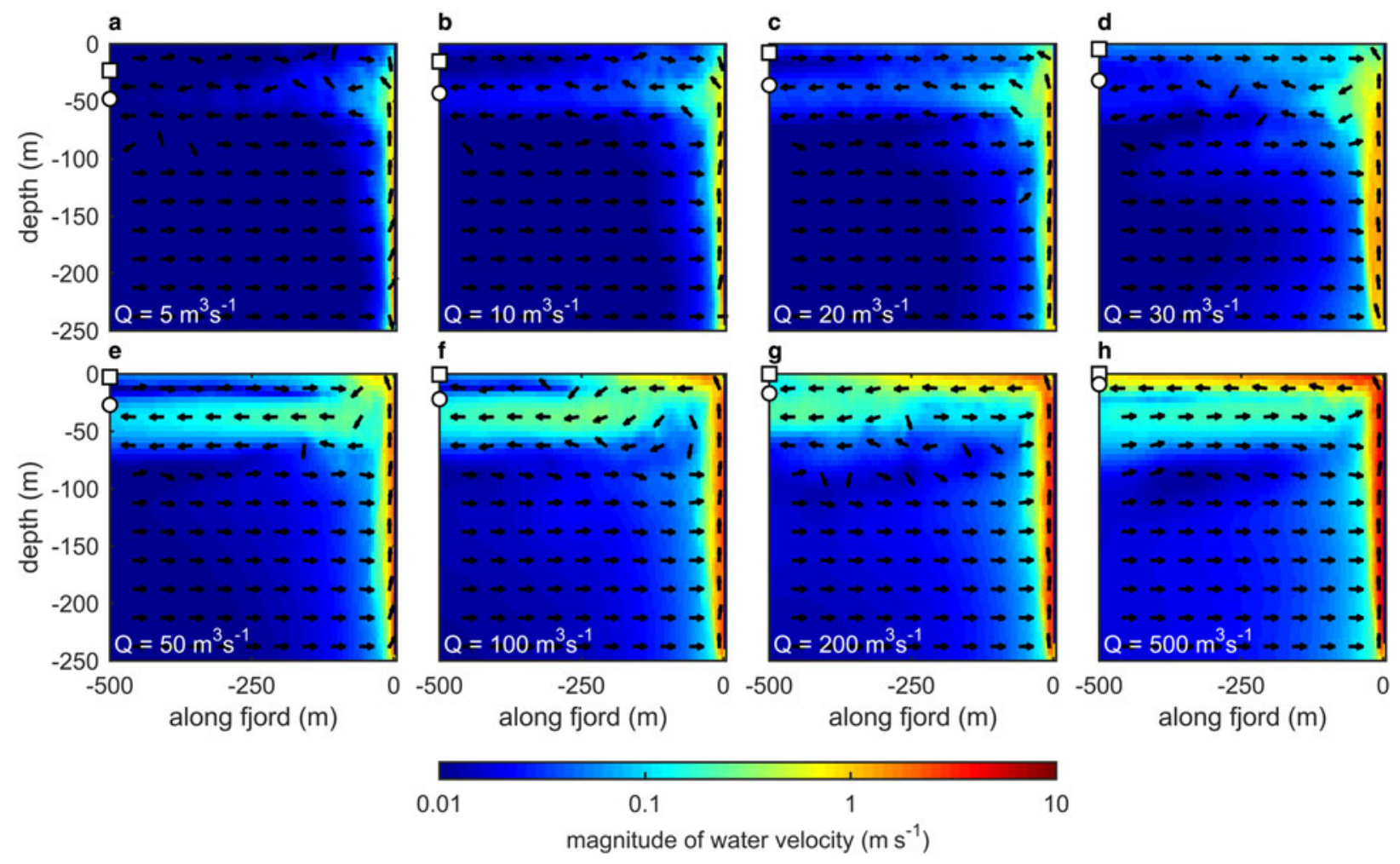

Fig. 4. Point source plume modelling in MITgcm. Plots show a cross-section along a fjord centreline, which passes through the centre of the plume. In each plot, the glacier is at the right and runoff enters at the grounding line at the bottom right, producing a plume. Subglacial discharge increases from (a) $5 \mathrm{~m}^{3} \mathrm{~s}^{-1}$ to (h) $500 \mathrm{~m}^{3} \mathrm{~s}^{-1}$. Note the logarithmic velocity colour scale and that the arrows indicate direction but not magnitude - of flow. Circular symbols indicate the height at which the plume salinity is equal to ambient salinity according to BPT (Fig. 3d), while square symbols indicate the maximum height reached by the plume according to BPT (Fig. 3b). The plots suggest a discharge of $50 \mathrm{~m}^{3} \mathrm{~s}^{-1}$ is required before the resulting plume will be visible at the fjord surface.

As subglacial discharge is increased, the modelled plume displays an increasing ability to drive a surface expression. At a discharge of $50 \mathrm{~m}^{3} \mathrm{~s}^{-1}$ (Fig. 4e) the plume does indeed reach the fjord surface. Water from within the plume then flows away from the glacier in a layer which is $20 \mathrm{~m}$ thick in the vertical and with velocities that exceed $1 \mathrm{~m} \mathrm{~s}^{-1}$ at the surface. Due to the entrainment of deeper saltier water, and in agreement with BPT (Fig. 3), water in the plume at the surface is denser than the ambient water. Plume water therefore remains at the surface for only $\sim 100 \mathrm{~m}$ from the glacier, thereafter diving back down to a level of neutral buoyancy at $\sim 40 \mathrm{~m}$ depth (Fig. 4e). We propose that this modelled situation corresponds to Figure 2c where a plume is visible at the fjord surface but confined within a few hundred metres of the glacier. With a subglacial discharge of $500 \mathrm{~m}^{3} \mathrm{~s}^{-1}$ (Fig. 4h), the plume drives surface velocities in excess of $3 \mathrm{~m} \mathrm{~s}^{-1}$ close to the glacier, and remains at the fjord surface for a number of kilometres (cf. Fig. 2d).

The maximum height reached by the plume according to BPT is plotted as square symbols in Figure 4, while the height at which the plume becomes denser than ambient fjord water according to BPT is plotted as circular symbols. The latter height is thought to be a good estimate of the depth at which a plume finds neutral buoyancy as it flows away from the glacier (Carroll and others, 2015). Comparison of the symbols from BPT with the MITgcm results shows very good agreement between the two methods, though BPT takes no account of mixing of fjord water as it flows away from the glacier, which may explain the slightly deeper outflowing layer for discharges of 50 and $100 \mathrm{~m}^{3} \mathrm{~s}^{-1}$ (Figs 4e, f).
Plots from BPT applied to line sources are shown in Figure 5. The results show the same qualitative features as for point sources, with larger subglacial discharges driving stronger plumes that reach closer to the fjord surface. Plumes initiated by discharges of $1 \mathrm{~m}^{2} \mathrm{~s}^{-1}$ and upwards reach the fjord surface but slow rapidly near the surface due to the fresh surface layer in the ambient fjord (Figs 5b, d). A discharge of $0.5 \mathrm{~m}^{2} \mathrm{~s}^{-1}$ generates a plume that reaches within $5 \mathrm{~m}$ of the fjord surface and carries a volume flux of $25 \mathrm{~m}^{2} \mathrm{~s}^{-1}$ at its maximum height.

We now return to the question of the critical subglacial discharge required for the resulting plume to be visible at the fjord surface. Based on BPT, discharges of $100 \mathrm{~m}^{3} \mathrm{~s}^{-1}$ for a point source and $1 \mathrm{~m}^{2} \mathrm{~s}^{-1}$ for a line source are required for the plume to reach the surface (Figs 3, 5). However, discharges of $50 \mathrm{~m}^{3} \mathrm{~s}^{-1}$ and $0.5 \mathrm{~m}^{2} \mathrm{~s}^{-1}$ result in plumes that reach within $5 \mathrm{~m}$ of the fjord surface and carry significant volume fluxes, which must flow away from the glacier in a layer of finite thickness. Modelling in MITgcm indeed suggests that a discharge of $50 \mathrm{~m}^{3} \mathrm{~s}^{-1}$ will drive a surface expression where plume water flows away from the glacier at the surface. By analogy it is reasonable to expect that a line source discharge of $0.5 \mathrm{~m}^{2} \mathrm{~s}^{-1}$ would be sufficient to drive a surface expression.

In this study, we consider $50 \mathrm{~m}^{3} \mathrm{~s}^{-1}$ or $0.5 \mathrm{~m}^{2} \mathrm{~s}^{-1}$ to be the critical subglacial discharge at which the resulting point or line source plume will drive an expression visible on the fjord surface. Note that a line source with discharge $0.5 \mathrm{~m}^{2} \mathrm{~s}^{-1}$ and width $100 \mathrm{~m}$ carries the same discharge as a point source with discharge $50 \mathrm{~m}^{3} \mathrm{~s}^{-1}$. 

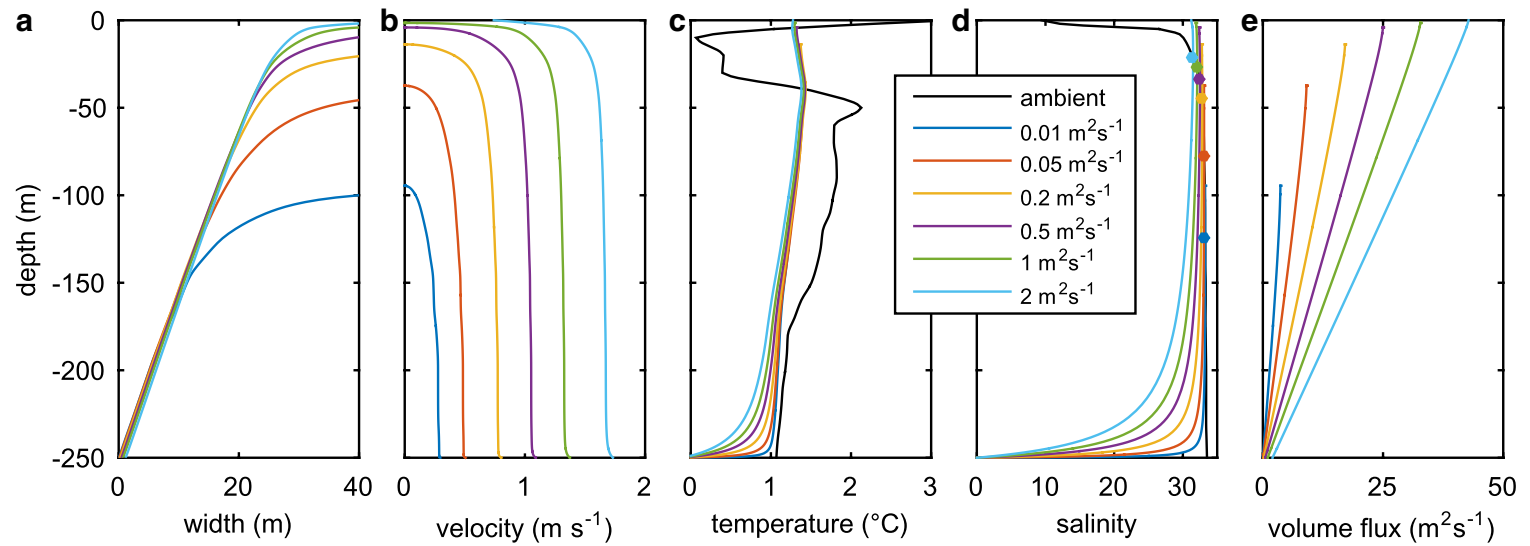

Fig. 5. Plume modelling in BPT assuming a low and very wide subglacial channel (line source), for discharge per unit width from 0.01 to $2 \mathrm{~m}^{2}$ $\mathrm{s}^{-1}$. A plume initiated by a discharge of $0.01 \mathrm{~m}^{2} \mathrm{~s}^{-1}$ reaches a maximum height $\sim 100 \mathrm{~m}$ below the fjord surface, while plumes resulting from discharges upwards of $0.5 \mathrm{~m}^{2} \mathrm{~s}^{-1}$ will reach - or effectively reach - the fjord surface.

We note that if there is ice mélange present at the fjord surface (e.g. Fig. 2b), then the surface expression of a plume may be inhibited, though this effect is very difficult to quantify. Our images show that ice mélange is present at the fjord surface throughout the summer of 2009. During periods of plume state 2 , ice melange in the centre of the fjord is flushed down-fjord (Fig. 2d), but after these events it quickly returns to cover the full fjord. The ice mélange appears fairly mobile in our time-lapse images, especially later in the melt season. In support of our choice of critical subglacial discharge, Bendtsen and others (2015) have estimated surface current velocities within a mélange-free surface plume of the order of $0.5 \mathrm{~m} \mathrm{~s}^{-1}$. This indicates that surface velocities of $1 \mathrm{~m} \mathrm{~s}^{-1}$, as modelled in our $50 \mathrm{~m}^{3} \mathrm{~s}^{-1}$ case, would be sufficient to locally clear ice mélange from in front of KNS and give a plume visible at the fjord surface.

\subsection{Plume visibility, catchment runoff and subglacial hydrology}

\subsubsection{Early melt season (days 110-192)}

Significant surface melting begins on day 135 following a rapid rise in air temperature (Figs 6a, b). The ice tongue (Fig. 2a) remains structurally intact until rapid disintegration on day 155 following a further increase in surface melting. There follows a period of $37 \mathrm{~d}$ during which there is no visible surface expression of a plume (Figs 2b, 6d) in spite of substantial modelled surface melting (Fig. 6b). Runoff in the 'PDD rapid' case (Fig. 6b, purple) is similar to surfacemelt production (Fig. 6b, green) and regularly exceeds 200 $\mathrm{m}^{3} \mathrm{~s}^{-1}$ from days 152 to 192 . Runoff as predicted by HIRHAM5 peaks at $750 \mathrm{~m}^{3} \mathrm{~s}^{-1}$ during a large rainfall event. In the 'PDD delayed' case (Fig. 6b, pink), peaks in runoff are delayed and smoothed, but between days 152 and 192, runoff still peaks at $250 \mathrm{~m}^{3} \mathrm{~s}^{-1}$ and is sustained at this level for $\sim 15 \mathrm{~d}$.

Modelled runoff in the early melt season therefore frequently exceeds the critical discharge required for a plume to show a surface expression. Considering first point sources, if at a given time there is no surface expression of a plume, our results suggest that no single channel is carrying a discharge $>50 \mathrm{~m}^{3} \mathrm{~s}^{-1}$. If at the same time runoff from the glacier into the fjord is $250 \mathrm{~m}^{3} \mathrm{~s}^{-1}$, there must be at least five independent subglacial channels, so that no individual plume reaches the fjord surface and creates a visible surface expression. If instead runoff is emerging as a line source and there is no surface expression of a plume, discharge per unit width at the source must not exceed $0.5 \mathrm{~m}^{2} \mathrm{~s}^{-1}$. If at the same time catchment runoff is $250 \mathrm{~m}^{3} \mathrm{~s}^{-1}$, this implies that the line source has a minimum width of $500 \mathrm{~m}$. Of course, point and line sources are idealised geometries and a realistic system may consist of a complex combination of the two. These idealised geometries nevertheless provide an informative first-order measure of the spatial spreading of runoff at the grounding line.

Modelled plume visibility for various runoff and hydrological scenarios are plotted in Figure 6e. A label P4/L400 indicates four independent point sources or a line source of width $400 \mathrm{~m}$. As described above, these are equivalent scenarios in terms of plume visibility. We expect that the structural integrity of the ice tongue would prevent a plume from reaching the surface before day 155 . The lack of plume visibility from days 155 to 192 can be reproduced by a drainage system consisting of eight independent point sources or a line source of width $800 \mathrm{~m}$ (Fig. 6e, P8/L800). It is certainly clear that in any runoff scenario, there cannot be a single large subglacial channel routing the majority of the runoff, as the resulting plume would be visible at the fjord surface continuously through the early melt season (Fig. 6e, P1/L100). We therefore argue that during the early melt season, the input of runoff into the fjord from beneath the glacier occurs in a spatially distributed fashion consisting of either numerous point sources, a wide line source, or some combination of the two.

\subsubsection{Mid-melt season (days 192-211)}

Surface melting increases from day 185 to a peak on day 195 , driven by air temperatures above zero even at high elevations (Fig. 6a). Over the following days surface melting decreases, but runoff remains high $\left(>250 \mathrm{~m}^{3} \mathrm{~s}^{-1}\right)$. A plume is first visible on day 192 in state 1 (Fig. 2c) before expanding to state 2 (Fig. 2d) on day 195 where it largely remains until day 206 (Fig. 6d). The plume is then visible mostly in state 1 until day 211 when it briefly disappears, meaning that a plume is consistently visible for 19 consecutive days in late July. While in state 1 the plume appears consistently in the location seen in Figure 2c. While in state 2 the surface expression 

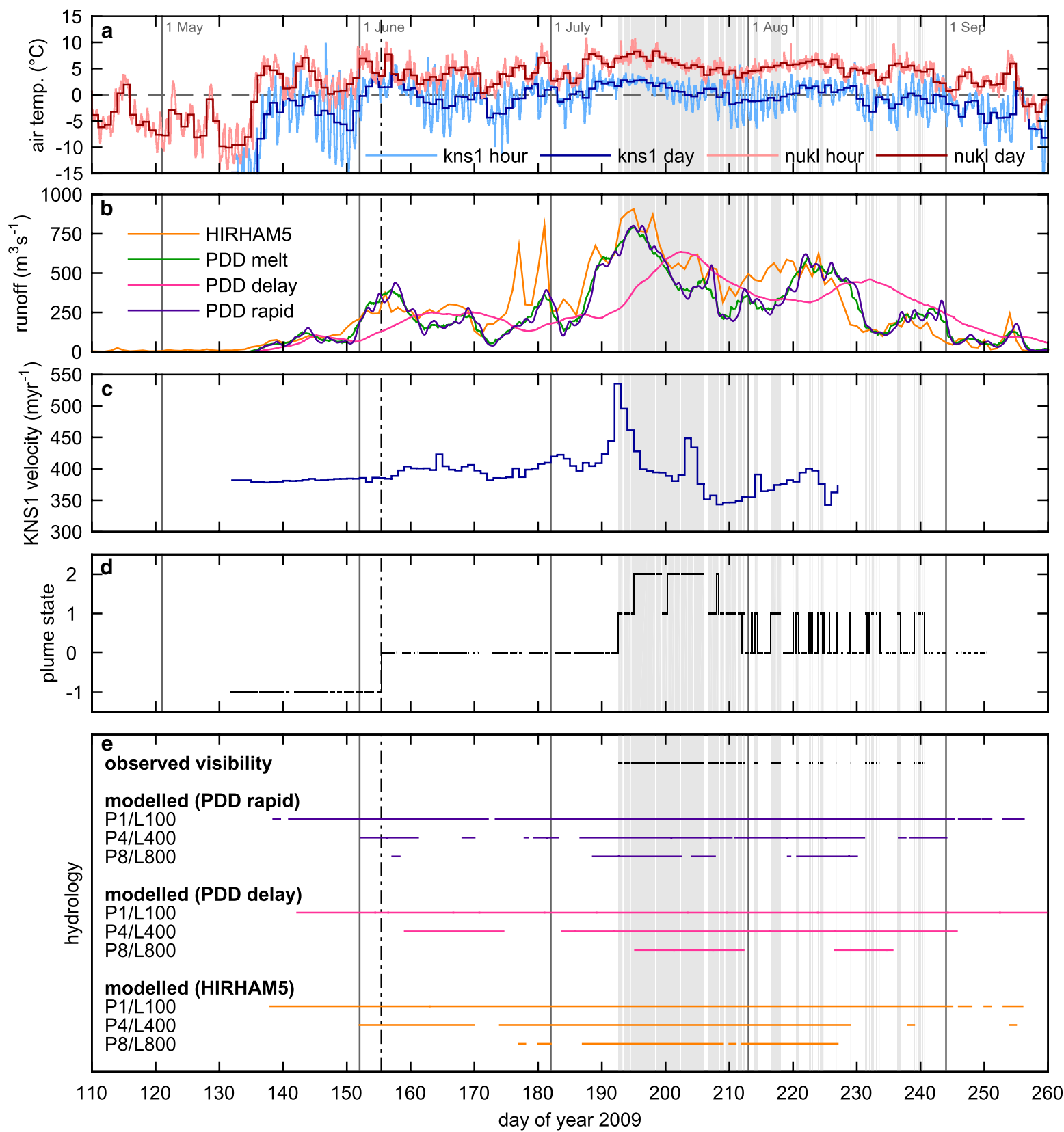

Fig. 6. (a) Air temperature from KNS1 and NUKL PROMICE stations (Fig. 1). (b) Modelled runoff. HIRHAM5 (orange) delays runoff using a parameterisation based on surface slope. PDD model (green) assumes instantaneous runoff. PDD delay (pink) uses a transit velocity of $0.05 \mathrm{~m} \mathrm{~s}^{-1}$ from point of production to the terminus. PDD rapid (purple) uses a transit velocity of $1 \mathrm{~m} \mathrm{~s}^{-1}$. The green curve has been smoothed using a $3 \mathrm{~d}$ moving window, the pink and purple curves using a $6 \mathrm{~h}$ moving window. Large discrepancies between HIRHAM5 and the PDD model arise due to rainfall events (e.g. days 177 and 181). (c) KNS1 daily ice velocity. (d) Plume state as described in Figure 2. (e) Plume visibility under various runoff and hydrological scenarios, for comparison with four observed plume visibility (top, black). P4 assumes four independent narrow subglacial channels (point sources), while L400 assumes a low and wide subglacial channel of $400 \mathrm{~m}$ width (line source). For example, assuming we had a single narrow subglacial channel and runoff according to the PDD delay scenario, a plume would be visible at the fjord surface continuously from days 142 to 260 . Dash-dot black line shows timing of ice tongue break-up.

of the plume occupies a significant width of the calving front $(\sim 2 \mathrm{~km})$ and there is infrequently a secondary plume on the eastern side of the fjord.

A record of ice velocity at KNS1 (Fig. 6c) shows a peak on day 192 , and the subsequent decrease of velocity to values below those in the early melt season is suggestive of the formation of efficient subglacial channels in the vicinity of KNS1 (Sole and others, 2011). The establishment of efficient channels would suggest that following peak runoff (day 2200), our 'rapid' meltwater transit scenario may be appropriate. We continue however to consider the end member 'rapid' and 'delayed' cases, with runoff from the former peaking at $800 \mathrm{~m}^{3} \mathrm{~s}^{-1}$ on day 195 and from the latter at $650 \mathrm{~m}^{3} \mathrm{~s}^{-1}$ on day 202 .

Runoff is sufficiently high in the mid-melt season that modelled plume visibility reproduces the observed visibility even for the most spatially distributed case considered, consisting of eight independent point sources or a line source of $800 \mathrm{~m}$ width (Fig. 6e, P8/L800). We may also compare the plume modelling with our observations of the fjord surface 
from our time-lapse imagery. On day 200, the plume flows down-fjord at the surface for a number of kilometres (Fig. 2d). Our modelling (Fig. 4) would suggest this requires upwards of $200 \mathrm{~m}^{3} \mathrm{~s}^{-1}$ from a point source or by analogy, upwards of $2 \mathrm{~m}^{2} \mathrm{~s}^{-1}$ from a line source. Since we have argued that in the early melt season focused runoff does not exceed $50 \mathrm{~m}^{3} \mathrm{~s}^{-1}$ from a point source or $0.5 \mathrm{~m}^{2} \mathrm{~s}^{-1}$ from a line source, there may be a focusing of runoff in the mid-melt season relative to the early melt season.

\subsubsection{Late melt season (days 211-260)}

From days 211 to 230 , surface melting remains high with a peak of $600 \mathrm{~m}^{3} \mathrm{~s}^{-1}$ on day 222 in the 'rapid' scenario and $450 \mathrm{~m}^{3} \mathrm{~s}^{-1}$ on day 232 in the 'delayed' scenario (Fig. 6e). On day 230 there is a marked decrease in melt with subsequent runoff remaining below $350 \mathrm{~m}^{3} \mathrm{~s}^{-1}$ before ceasing on day 257 . In the late melt season, plume surface expression is sporadic, with frequent switching between states 0 and 1 (Fig. 6d). This variability has no diurnal pattern (i.e. plumes do not appear or disappear at the same time of day), which is consistent with observed muted diurnal variability in runoff from large glacial catchments in Greenland (Cowton and others, 2013). The plume does however appear in a preferred location, similar to or slightly west of the plume seen in Figure 2c. The plume is last seen on day 240, with the last of our images taken on day 250.

The lack of correspondence between variability in runoff and plume visibility means that none of our hydrological scenarios reproduce the observed sporadic plume visibility (Fig. 6e). Runoff during the period of plume fluctuation remains high and would certainly be large enough to sustain a plume at the fjord surface continuously if all runoff was emerging from a single narrow subglacial channel. Therefore our inference is that in the late melt season runoff emerges into the fjord in a spatially distributed fashion, with sporadic focusing resulting in a plume visible at the fjord surface. In the late melt season, the hydrological system thus appears rather unstable, a point we return to below.

\subsection{Summary of results}

The hydrological scenario that most closely matches the observed plume visibility throughout the season consists of eight independent point sources or a line source of $800 \mathrm{~m}$ width (Fig. 6e, P8/L800). This spatially distributed scenario broadly reproduces the lack of plume visibility in the early melt season and the onset of a visible plume in the midmelt season. Of course the hydrological system may also evolve through the season; the observed plume visibility would also be recreated by a system that is more spatially distributed than the P8/L800 scenario in the early melt season and less spatially distributed than the P8/L800 scenario in the mid-melt season. The oscillatory nature of plume visibility in the late melt season is not captured by any of our runoff and hydrological scenarios, and is suggestive of a highly dynamic system.

However, our images only rarely show more than one distinct plume, and the plume is often observed in the same location. This may reflect a preferred location for runoff that is the largest of many point sources. In the mid-melt season, the significant width of calving front in contact with the plume may be indicative of a wide subglacial channel or perhaps a number of closely spaced point sources with plumes merging before the fjord surface. Based on scalings in Cenedese and Gatto (2016) and a terminus fjord depth of $250 \mathrm{~m}$, two point sources at KNS separated by $\$ 70 \mathrm{~m}$ will generate plumes that interact, potentially reducing entrainment and helping the plumes to reach the fjord surface.

It is certainly clear that there cannot be a single narrow subglacial channel routing the majority of the runoff throughout the melt season; the models predict that this would result in a plume continuously visible at the fjord surface from day 155 to beyond day 250 (Fig. 6e, P1/L100), and this is not observed. Under consistently high runoff (Fig. 6b), we instead we see a plume only periodically. The broad conclusion from our results is therefore that for much of the melt season runoff emerges into the fjord at the grounding line in a spatially distributed and diffuse fashion.

\section{SENSITIVITIES}

Of critical importance to the conclusions drawn in this paper are the estimates of catchment runoff and the critical discharge required for a plume to reach the surface. In this section, we describe possible sources of error on these estimates. Sensitivities are presented for a point source of $50 \mathrm{~m}^{3} \mathrm{~s}^{-1}$ discharge; results for line source plumes (not shown) are similar.

We first consider catchment runoff. HIRHAM5 has demonstrated the ability to simulate catchment runoff accurately in the Godthåbsfjord region (Langen and others, 2015). The degree day factors for ice $\left(11.9 \mathrm{~mm} \mathrm{~d}^{-1}{ }^{\circ} \mathrm{C}^{-1}\right)$ and for snow $\left(4.5 \mathrm{~mm} \mathrm{~d}^{-1}{ }^{\circ} \mathrm{C}^{-1}\right.$ ) used in our PDD model are comparable to or slightly higher than values previously reported for Greenland, a fact which may be explained by the high elevations of KNS1-4 (Braithwaite, 1995; Hock, 2003). The PDD approach is simple, but nevertheless compares well with the more sophisticated HIRHAM5 (Fig. 6b). The agreement between these two independent approaches gives us confidence in our estimates of catchment runoff. Perhaps the greatest uncertainty in runoff comes from lack of knowledge of the transit time of meltwater from production to when it enters the fjord. We have however shown by considering end members that this complication does not affect our broad conclusions.

In our plume modelling, we use ambient fjord conditions sampled on 5 August 2009 (Figs 3c, d) 35 km from the terminus of KNS (Mortensen and others, 2013). The significant distance from the terminus means that the stratification at the calving front could differ from the profile we use; dense ice mélange prevented detailed surveying of the fjord closer to the terminus. The ambient fjord conditions also show a seasonal evolution with a freshening of water close to the surface during the summer months (Mortensen and others, 2013). To test how plume dynamics respond to seasonal changes in fjord stratification, we ran BPT with ambient profiles from 8 February and 15 September 2009 (Figs 7a, b). The lack of a fresh surface layer in the February profile means that the plume reaches the surface more easily, while use of the September profile produces only very minor differences relative to the default 5 August profile (Figs 7c-g). Observations by Mortensen and others (2013) suggest that the fresh surface layer is well established by late June and that the August profile is therefore likely representative of the stratification for much of the summer. In May and early June, it is possible that the fresh surface layer is absent (Mortensen and others, 2013); however, our modelling suggests that this makes it 
a

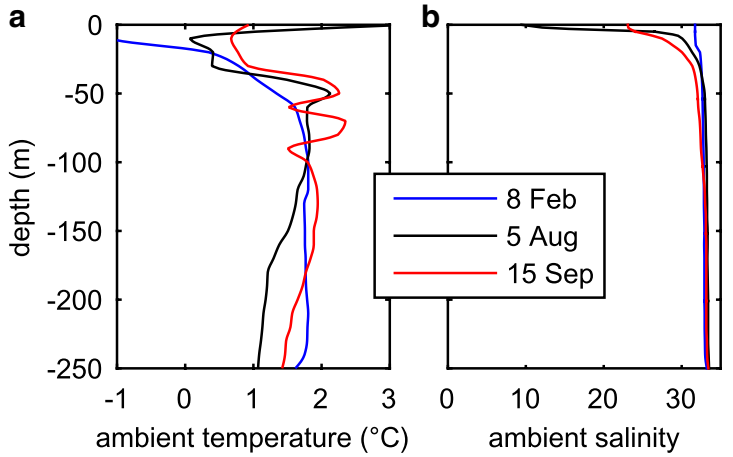

C
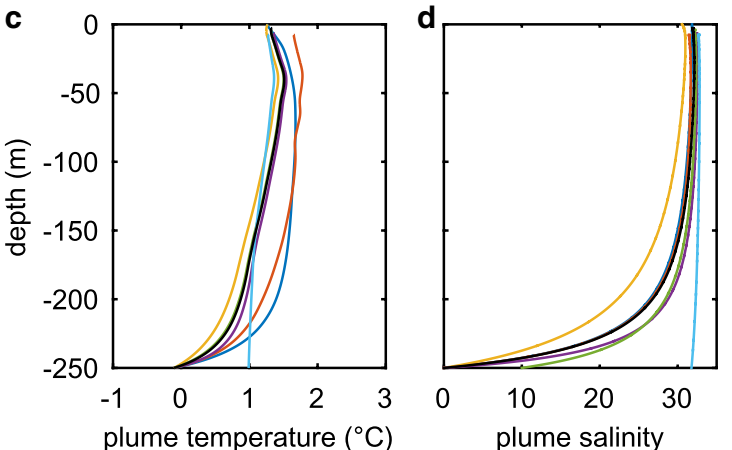
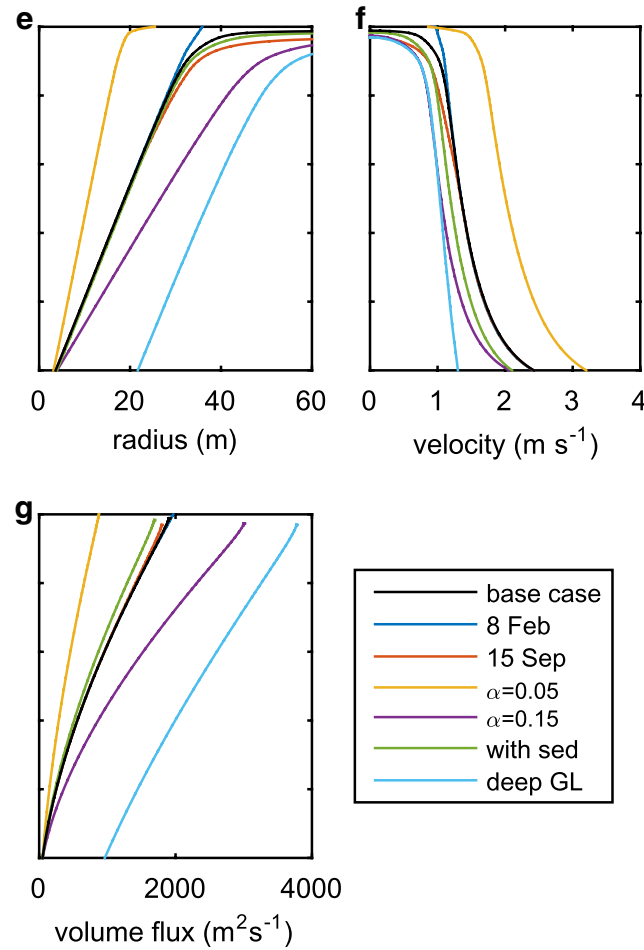

Fig. 7. (a) Temperature and (b) salinity profiles from the proglacial fjord in 2009, digitised from Mortensen and others (2013). The 8 February profile was taken $\sim 10 \mathrm{~km}$ from KNS, while the 5 August and 15 September profiles were taken $\sim 35 \mathrm{~km}$ from KNS. Main plume modelling results shown in Figures 3-5 use the profile from 5 August. Panels (c)-(g) show sensitivity experiments for a point source plume with 50 $\mathrm{m}^{3} \mathrm{~s}^{-1}$ subglacial discharge. Black lines in (c)-(g), labelled 'base case', indicate the default case plotted in Figure 3 . Sensitivities considered are '8 Feb': uses 8 February ambient profiles, '15 Sep' uses 15 September ambient profiles, ' $\alpha=0.05$ ' uses a small entrainment coefficient, ' $\alpha=0.15$ ' uses a high entrainment coefficient, 'with sed' considers a plume with sediment, as described in the text, and 'deep $\mathrm{GL}^{\prime}$ considers a deeper grounding line at $400 \mathrm{~m}$ depth (only the $250 \mathrm{~m}$ closest to the fjord surface are plotted).

easier for a plume to reach the surface, thus lowering the critical discharge needed for the plume to reach the fjord surface and strengthening our conclusions regarding the distributed nature of subglacial discharge. In summary, our analysis suggests that seasonal changes in stratification do not affect our conclusions.

The rate at which the plume entrains ambient fjord water is parameterised in BPT by assuming that the degree of entrainment is proportional to the vertical velocity of the plume (Morton and others, 1956). The constant of proportionality, $\alpha$, has been set here to 0.1 , and the mixing parameters in our MITgcm modelling have also been tuned to this value (Slater and others, 2015). However, this turbulence closure has not yet received validation in the specific case of proglacial discharge plumes adjacent to tidewater glaciers, and furthermore some authors advocate slightly different values of $\alpha$ (e.g. Turner, 1973). To test the sensitivity of our results to this choice, we considered low $(\alpha=0.05)$ and high $(\alpha=0.15)$ values, which span the range of values in the literature. The value of $\alpha$ strongly affects plume dynamics; a higher value results in a plume with a larger width and volume flux, but lower velocity (Figs 7c-g). However, the value of $\alpha$ does not here strongly affect the height reached by the plume; use of $\alpha=0.15$ results in a plume with maximum height within $4 \mathrm{~m}$ of a plume having $\alpha=0.1$. Therefore, for these ambient conditions, the critical discharge required for a plume to reach the fjord surface does not depend strongly on the value of $\alpha$.

Proglacial discharge plumes can contain significant volumes of sediment (Tedstone and Arnold, 2012), which may alter the dynamics of the plume. The presence of suspended sediment in the plume would act to increase the density of plume water, thus decreasing plume buoyancy. As the plume rises, mixing with ambient water would decrease the sediment concentration. An assessment of the importance of sediment can be achieved by increasing the density of subglacial discharge by using a non-zero initial salinity. We model a plume with an initial salinity of 10 , resulting in a reduction in plume buoyancy equivalent to a sediment load of $8 \mathrm{~kg} \mathrm{~m}^{-3}$, which may be considered high for Greenland subglacial discharge (Cowton and others, 2012). The sediment-laden plume is, as expected, weaker than without sediment yet it still shows good evidence of reaching the fjord surface (Figs $7 \mathrm{c}$, d, 'with sed'). The relatively small effect of this sediment load on plume dynamics may be explained by the sub-linear relationship between plume velocity and initial plume buoyancy (Slater and others, 2016), meaning that plume dynamics are quite insensitive to initial plume buoyancy.

The bathymetry near the grounding line at KNS is not known in great detail. A grounding line depth of $250 \mathrm{~m}$ has been widely assumed (Lea and others, 2014; Mortensen and others, 2014; Bendtsen and others, 2015); however, we recognise that the grounding line depth of KNS could conceivably be somewhat greater and display across-fjord variability. To test the sensitivity of our results to a deeper grounding line we ran BPT with a grounding line depth of $400 \mathrm{~m}$. CTD profiles from further down-fjord where the bathymetry is deeper than $250 \mathrm{~m}$ indicate that the fjord is very weakly stratified at depth (Mortensen and others, 2014), therefore we use the values of temperature and salinity at $250 \mathrm{~m}$ depth to fill the depth range from 250 to $400 \mathrm{~m}$. 
Under this scenario, the modelled plume (Figs 7c-g, 'deep $\mathrm{GL}^{\prime}$ ) still reaches the fjord surface due to the weak fjord stratification at depth and relatively thin fresh surface layer. We therefore suggest that our conclusions will hold even if future surveys reveal that KNS has a significantly deeper grounding line than currently believed.

A final important point is that our plume modelling has assumed that the calving front at KNS is flat and vertical. Side-scan sonar has recently shown that the calving fronts of a number of tidewater glaciers in West Greenland can be substantially undercut and deeply incised in the location of plumes (Fried and others, 2015; Rignot and others, 2015). The confinement of a plume within an incision into the ice could potentially modify the rate of mixing between the plume and ambient fjord water, thus affecting its likelihood of reaching the fjord surface. Such feedbacks between the shape of the calving front and the dynamics of the plume are not captured by our modelling.

\section{DISCUSSION}

\subsection{Near-terminus subglacial hydrology}

Our modelling suggests that for most of the 2009 melt season, runoff volumes easily exceed the critical discharge required to produce a plume visible at the fjord surface. Yet particularly in the early and late melt seasons, plumes are only intermittently visible. Based on these observations, we argue that runoff must often emerge into the fjord in a spatially distributed fashion, either through numerous narrow channels, a single but very wide channel, or through some other complex and diffuse system. Spatially distributed hydrological systems are associated with high basal water pressure (Fountain and Walder, 1998); our findings are therefore qualitatively consistent with borehole water pressure records from near the termini of calving glaciers, which have found basal water pressures close to ice overburden (Meier and others, 1994; Vieli and others, 2004; Sugiyama and others, 2011). Furthermore, high basal water pressures are associated with low basal drag, and our results are therefore also consistent with recent ice model inversions, which found that the beds beneath fast-flowing glaciers in Greenland provide almost no resistance to flow (Shapero and others, 2016).

Distributed subglacial hydraulic systems may take the form of networks of linked subglacial cavities or saturated subglacial sediments with channels incised into the bed (e.g. Fountain and Walder, 1998). Our results do not permit us to differentiate between these morphologies and both may plausibly persist near the terminus of KNS.

The presence of deforming subglacial sediment is thought to be fundamental to the fast flow of Antarctic ice streams (e.g. Alley and others, 1986) and there is some evidence for the presence of thick layers of sediment beneath the Greenland ice sheet (Walter and others, 2014). Walder and Fowler (1994) developed a theoretical framework for subglacial drainage in saturated, deformable till, suggesting that under conditions of high subglacial discharge, low effective pressure and low surface slope (all of which are likely satisfied at the terminus of KNS), drainage may occur stably through shallow and wide canals incised into the subglacial sediment. It is plausible that such a drainage system exists near the terminus of KNS, with the resulting low effective pressure driving high ice velocity, and the wide and distributed nature of canals spreading runoff across the grounding line and resulting in plumes only intermittently visible at the fjord surface.

Alternatively, distributed drainage may take place in a network of linked subglacial cavities, and there is theoretical support (e.g. Fowler, 1987; Kamb, 1987; Schoof, 2010) for the prevalence of this style of drainage when ice slides rapidly over its bed. Such work was initially motivated by the study of surging glaciers, but is equally applicable to the fast flowing termini of calving glaciers. These theoretical studies consider drainage through Röthlisberger channels and linked cavities in the presence of basal sliding. Each suggests a transition between drainage through channels and drainage through cavities that depends on sliding velocity and the magnitude of subglacial discharge. For low sliding velocity and high subglacial discharge, drainage through cavities is unstable and drainage will preferentially take place through channels. For high sliding velocity and low subglacial discharge, drainage through efficient channels is unstable and will instead take place through a network of linked cavities (Fowler, 1987; Kamb, 1987; Schoof, 2010).

We do not attempt quantitative application of these idealised theories to the terminus of KNS as this would require values for a number of poorly constrained parameters. Nevertheless it is plausible that the extremely high sliding velocities near the terminus of KNS $\left(\sim 20 \mathrm{~m} \mathrm{~d}^{-1}\right.$, Fig. 1) might render efficient subglacial channels unstable and promote drainage through an inefficient network of linked subglacial cavities. This could explain the spatially distributed nature of subglacial runoff inferred from our plume observations.

One may also consider the seasonal evolution of the drainage system near the terminus of KNS. In the early melt season, when we see sustained runoff but no plume, the drainage system might be expected to exist stably as a network of linked cavities. The increase in runoff in the mid-melt season could be sufficient to cross the threshold into channelised drainage, while the oscillation of plume visibility in the late melt season might be indicative of a system which is close to the cavity/channel threshold (Kamb, 1987). Equally, much of the variability in plume visibility can be captured by a single hydrological scenario (e.g. P8/L800 in Fig. 6e), providing evidence for a hydrological system that is fairly static but spatially distributed throughout the melt season.

We acknowledge that much of this discussion is speculative and it will require much further study to elucidate the precise nature of the hydrological system near the terminus of KNS. Consideration of a longer dataset spanning multiple years might be illuminating, particularly if there is significant interannual variability in runoff. It would also be interesting to further evaluate our arguments by investigating - along similar lines to that undertaken in this study - a much slower flowing tidewater glacier. According to the theories of transition between channelised and distributed drainage discussed above, a slower flowing tidewater glacier would more readily form efficient channels near the terminus and should therefore have a plume visible at the fjord surface more frequently (once catchment runoff and fjord stratification have been taken into account).

Three recent studies present results that are consistent with our arguments. At fast flowing Rink Glacier in West Greenland, Bartholomaus and others (2016) suggest that routing all runoff through a single narrow subglacial channel would give a plume visible at the fjord surface far 
more frequently than is observed. At the same glacier and based on the presence of plumes visible at the fjord surface long after surface melting had ceased, Schild and others (2016) argued for significant subglacial storage of meltwater and therefore a distributed hydrological system. Finally, Fried and others (2015) mapped the terminus morphology at Kangerlussuup Sermia (KS), West Greenland, finding at least seven distinct submarine cavities in the calving front, only a few of which were associated with plumes visible at the fjord surface. Despite the significantly lower ice velocity at $\mathrm{KS}$, these observations indicate that there are similarities with the drainage system we infer at KNS, with runoff spread between multiple conduits at the grounding line, and the resulting plumes not necessarily visible at the fjord surface.

\subsection{Implications for ice dynamics}

The structure and evolution of the subglacial hydrological system exert a strong control on ice velocity. We here discuss the possible implications of our findings for ice motion at KNS.

Land-terminating glaciers in Greenland show a hydrologically induced seasonal cycle in ice motion, often displaying slowest motion in late summer during periods of stable or decreasing runoff when efficient channels reduce basal water pressure over a significant area of the bed (e.g. Bartholomew and others, 2010; Andrews and others, 2014). Sole and others (2011) report that ice velocities at KNS in summer 2009 show this same evolution between 35 and $48 \mathrm{~km}$ from the glacier terminus. Remote sensing of ice velocity (Moon and others, 2014; Fahnestock and others, 2015) extends evidence for this behaviour to within a few kilometres of the KNS terminus. Similarly, Howat and others (2010) showed that a number of tidewater glaciers further north in Greenland display the same seasonal evolution of ice velocity, which they infer is driven by the evolution of subglacial drainage.

However, the extent to which this evolution occurs within the last few kilometres before the glacier terminus remains unclear. Our results suggest that efficient subglacial channels do not persist near the terminus. In the late melt season, it may then be the case that efficient channels exist further inland, but that runoff from these channels spreads as it approaches the terminus region. This spreading might be initiated as the channel approaches the terminus where the glacier becomes close to flotation and basal sliding becomes sufficiently high (Fig. 1) to render Röthlisberger channels unstable (Fowler, 1987; Kamb, 1987; Schoof, 2010).

In a distributed system which shows resistance to channelisation, as we infer exists near the terminus of KNS, water pressure increases with runoff (Kamb, 1987) and therefore ice velocity would be expected to scale with runoff. Such behaviour has been observed at lake-terminating Glacier Perito Moreno in Patagonia (Sugiyama and others, 2011) and Moon and others (2014) have argued for similar behaviour at a number of marine-terminating glaciers around Greenland. Thus, under distributed subglacial drainage, increased surface melting may increase basal lubrication and drive tidewater glacier acceleration. Using an idealised model, Pfeffer (2007) has suggested that increasing basal lubrication can lead to irreversible tidewater glacier retreat.

Testing these hypotheses requires high temporal resolution records of ice velocity at the terminus, in order to disentangle hydrologically forced changes in ice motion over various timescales from other terminus processes affecting ice velocity such as loss of buttressing and terminus retreat. However, we believe that our results provide motivation for further study of near-terminus subglacial hydrology, and suggest that consideration of only a single point on the glacier surface (e.g. Howat and others, 2010; Moon and others, 2014) may not resolve spatial heterogeneity in glacier dynamics.

\subsection{Implications for submarine melting}

We finally consider the implications of our results for submarine melting of the calving front of KNS. Both MITgcm and BPT include submarine melting, but submarine melting has not been the focus of this paper and we include only a brief discussion here drawing on previous modelling.

Slater and others (2015) showed that more distributed near-terminus subglacial hydrology leads to more homogeneous submarine melting across the glacier calving front and higher total submarine melt volumes. Based on these results, splitting discharge over eight channels (hydrological scenario P8, Fig. 6e) would elevate total submarine melting by a factor 3.5 over the single-channel case. However, a completely distributed hydrological scenario considered in Slater and others (2015), using comparable discharge and warmer water than that recorded at KNS, resulted in an average melt rate of $3.6 \mathrm{~m} \mathrm{~d}^{-1}$. Thus, the average submarine melt rates at KNS are likely to be substantially smaller than the ice velocity of $\sim 20 \mathrm{~m} \mathrm{~d}^{-1}$, irrespective of near-terminus subglacial hydrology. Routing the majority of subglacial discharge through a single channel can give very high localised melt rates of $\sim 10 \mathrm{~m} \mathrm{~d}^{-1}$ in the vicinity of the channel ( $\mathrm{Xu}$ and others, 2013; Kimura and others, 2014), which approaches but is still smaller than the ice velocity at KNS. It is worth noting that even if submarine melting cannot match ice velocity, it may still play a role in terminus stability by undercutting the terminus, potentially influencing calving.

It should of course also be noted that these melt rates are based on a parameterisation that has yet to receive validation at a tidewater glacier (Holland and Jenkins, 1999; Straneo and Cenedese, 2015). Nevertheless, under current modelling understanding, submarine melt rates at KNS may not pace ice velocity even in a localised fashion, and when spatially averaged over the terminus, are nearly an order of magnitude smaller than ice velocity.

\section{CONCLUSION}

We have combined modelled catchment runoff and plume dynamics with a record of plume surface expression to investigate near-terminus subglacial hydrology at KNS, a large tidewater glacier in South-west Greenland. For a large proportion of the summer, the catchment runoff greatly exceeds the discharge required to create a plume that would reach the fjord surface, yet there are extended periods when there is no plume visible. This can only be explained by the runoff emerging into the fjord in a spatially distributed fashion. We thus argue that subglacial drainage near the glacier terminus is often spatially distributed, formed either from numerous point sources of subglacial discharge, a single but very wide subglacial channel or possibly a complex combination of the two. We have discussed how these features may be incised into subglacial sediment or ice, 
and in the latter case how rapid basal sliding might destabilise efficient channels near the terminus.

Our arguments have a number of possible implications. Firstly, distributed subglacial drainage at the terminus will lead to more homogeneous submarine melting of the calving front and higher total submarine melt volumes. Under current modelling understanding, however, spatially averaged submarine melt rates at KNS are at least an order of magnitude smaller than the terminus ice velocity, and even very focused and high-magnitude subglacial discharge cannot induce local melt rates matching the terminus ice velocity. Secondly, the structure and evolution of the subglacial drainage system exerts an important control on ice velocity. Inland from the terminus the formation of efficient subglacial channels leads to a pronounced and sustained decrease in ice velocity in late summer (Sole and others, 2011; Moon and others, 2014; Fahnestock and others, 2015). If pervasive distributed drainage exists near the terminus, ice velocity in the terminus region may respond to meltwater forcing differently to ice further inland. In particular, ice velocity in the terminus region may then scale with catchment runoff

Finally, we note that in the absence of a sub-diurnal temporal resolution record of ice velocity, we cannot fully evaluate these arguments in this study. We hope that this work will provide motivation for further study of near-terminus subglacial hydrology at tidewater glaciers. Joughin and others (2008) have suggested that surface melt induced speed-up of tidewater glaciers is of only small relative magnitude near the terminus and therefore less important than other processes such as terminus retreat. However, it remains possible that increased surface melting may be the driver of terminus retreat; increased surface melt entering a pervasive distributed drainage system will lead to increased basal lubrication, and subsequently acceleration and thinning. This mechanism has the potential to drive unstable retreat as described by Pfeffer (2007) and could therefore provide an alternative to or amplifier of ocean forcing in explaining tidewater glacier change in Greenland, particularly for glaciers where modelled submarine melt rates are very much smaller than ice velocity.

\section{ACKNOWLEDGEMENTS}

DAS is supported by a UK Natural Environmental Research Council PhD studentship. We acknowledge NERC Grants NE/K015249/1 and NE/F021399/1 (to PWN), NE/K014609/ 1 (to AJS) and NE/H024964/1 (to DWFM). The research leading to these results has also received funding (to RHM and PLL) from the European Research Council under the European Community's Seventh Framework Programme (FP7/2007-2013)/ERC grant agreement 610055 as part of the ice2ice project. Data from the Programme for Monitoring of the Greenland Ice Sheet (PROMICE) were provided by the Geological Survey of Denmark and Greenland (GEUS) at http://www.promice.dk.

\section{REFERENCES}

Ahlstrom AP and 13 others and PROMICE Project Team (2008) A new programme for monitoring the mass loss of the Greenland ice sheet. Geol. Surv. Denmark Greenland Bull., 15, 61-64

Ahlstrom AP and 13 others (2013) Seasonal velocities of eight major marine-terminating outlet glaciers of the Greenland ice sheet from continuous in situ GPS instruments. Earth Syst. Sci. Data, 5(2), 277-287 (doi: 10.5194/essd-5-277-2013)
Alley RB, Blankenship DD, Bentley CR and Rooney ST (1986) Deformation of till beneath ice stream $b$, west Antarctica. Nature, 322(6074), 57-59 (doi: 10.1038/322057a0)

Andrews LC and 7 others (2014) Direct observations of evolving subglacial drainage beneath the Greenland ice sheet. Nature, $\mathbf{7 5 2 0}$ (514), 80-83 (doi: 10.1038/nature13796)

Bartholomaus TC and 11 others (2016) Contrasts in the response of adjacent fjords and glaciers to ice-sheet surface melt in west Greenland. Ann. Glaciol., 57, 25-38 (doi: 10.1017/aog.2016.19)

Bartholomew I and 5 others (2010) Seasonal evolution of subglacial drainage and acceleration in a Greenland outlet glacier. Nat. Ceosci., 3, 408-411 (doi: 10.1038/ngeo863)

Bendtsen J, Mortensen J and Lennert K and Rysgaard S (2015) Heat sources for glacial ice melt in a west Greenland tidewater outlet glacier fjord: the role of subglacial freshwater discharge. Geophys. Res. Lett., 42(10), 4089-4095 (doi: 10.1002/ 2015GL063846)

Braithwaite RJ (1995) Positive degree-day factors for ablation on the Greenland ice sheet studied by energy-balance modelling. J. Glaciol., 41(137), 153-160 (doi: 10.3198/1995JoG41-137153-160)

Campbell FM, Nienow PW and Purves RS (2006) Role of the supraglacial snowpack in mediating meltwater delivery to the glacier system as inferred from dye tracer investigations. Hydrol. Process., 20(4), 969-985 (doi: 10.1002/hyp.6115)

Carroll D and 5 others (2015) Modeling turbulent subglacial meltwater plumes: implications for fjord-scale buoyancy-driven circulation. J. Phys. Oceanogr., 45(8), 2169-2185 (doi: 10.1175/ JPO-D-15-0033.1)

Carroll D and 11 others (2016) The impact of glacier geometry on meltwater plume structure and submarine melt in Greenland fjords. Geophys. Res. Lett., 43(18), 9739-9748 (doi: 10.1002/ 2016GL070170)

Cenedese C and Gatto VM (2016) Impact of two plumes' interaction on submarine melting of tidewater glaciers: a laboratory study. J. Phys. Oceanogr., 46(1), 361-367 (doi: 10.1175/JPO-D-150171.1)

Christoffersen P and 7 others (2011) Warming of waters in an east Greenland fjord prior to glacier retreat: mechanisms and connection to large-scale atmospheric conditions. Cryosphere, 5(3), 701-714 (doi: 10.5194/tc-5-701-2011)

Cowton T, Nienow P, Bartholomew I, Sole A and Mair D (2012) Rapid erosion beneath the Greenland ice sheet. Geology, 40 (4), 343-346 (doi: 10.1130/G32687.1)

Cowton T and 7 others (2013) Evolution of drainage system morphology at a land-terminating Greenlandic outlet glacier. J. Geophys. Res.: Earth Surf., 118(1), 29-41 (doi: 10.1029/2012JF002540)

Cowton T, Slater D, Sole A, Goldberg D and Nienow P (2015) Modeling the impact of glacial runoff on fjord circulation and submarine melt rate using a new subgrid-scale parameterization for glacial plumes. J. Geophys. Res.: Oceans, 120(2), 796-812 (doi: 10.1002/2014JC010324)

Enderlin EM and 5 others (2014) An improved mass budget for the Greenland ice sheet. Geophys. Res. Lett., 41, 866-872 (doi: 10.1002/2013GL059010)

Eorola K (2006) About the performance of hirlam version 7.0. HIRLAM Newsletter, No. 51, HIRLAM-A Programme, De Bilt, Netherlands, 93-102

Fahnestock M and 5 others (2015) Rapid large-area mapping of ice flow using landsat 8. Remote Sens. Environ., 185, 84-94 (doi: 10.1016/j.rse.2015.11.023)

Fettweis X, Mabille G, Erpicum M, Nicolay S and Van den Broeke M (2011) The 1958-2009 Greenland ice sheet surface melt and the mid-tropospheric atmospheric circulation. Clim. Dyn., 36(1), 139-159 (doi: 10.1007/s00382-010-0772-8)

Fountain AG and Walder JS (1998) Water flow through temperate glaciers. Rev. Geophys., 36(3), 299-328 (doi: 10.1029/ 97RG03579)

Fowler AC (1987) Sliding with cavity formation. J. Glaciol., 33(115), 255-267 (doi: 10.3198/1987JoG33-115-255-267) 
Fried MJ and 8 others (2015) Distributed subglacial discharge drives significant submarine melt at a Greenland tidewater glacier. Geophys. Res. Lett., 42(21), 9328-9336 (doi: 10.1002/ 2015GL065806)

Hewitt IJ (2013) Seasonal changes in ice sheet motion due to melt water lubrication. Earth Planet. Sci. Lett., 371-372, 16-25 (doi: 10.1016/j.epsl.2013.04.022)

Hock R (2003) Temperature index modelling in mountain areas. J. Hydrol., 282, 104-115 (doi: 10.1016/S0022-1694(03)00257-9)

Holland DM and Jenkins A (1999) Modeling thermodynamic iceocean interactions at the base of an ice shelf. J. Phys. Oceanogr., 29(8), 1787-1800 (doi: 10.1175/1520-0485(1999) $029<1787$ :MTIOIA > 2.0.CO;2)

Holland DM, Thomas $\mathrm{RH}$, de Young B, Ribergaard $\mathrm{MH}$ and Lyberth B (2008) Acceleration of Jakobshavn Isbrae triggered by warm subsurface ocean waters. Nat. Geosci., 1(10), 659664 (doi: 10.1038/ngeo316)

Howat IM, Box JE, Ahn Y, Herrington A and McFadden EM (2010) Seasonal variability in the dynamics of marine-terminating outlet glaciers in Greenland. J. Glaciol., 56(198), 601-613 (doi: 10.3189/002214310793146232)

Howat IM, Negrete A and Smith BE (2014) The Greenland ice mapping project (gimp) land classification and surface elevation data sets. Cryosphere, 8(4), 1509-1518 (doi: 10.5194/tc-8-15092014)

Iken A and Bindschadler RA (1986) Combined measurements of subglacial water pressure and surface velocity of findelengletscher, Switzerland: conclusions about drainage system and sliding mechanism. J. Glaciol., 32(110), 101-119 (doi: 10.3198/1986JoG32-110-101-119)

Jenkins A (2011) Convection-driven melting near the grounding lines of ice shelves and tidewater glaciers. J. Phys. Oceanogr., 41(12), 2279-2294 (doi: 10.1175/JPO-D-11-03.1)

Joughin I and 5 others (2008) Seasonal speedup along the western flank of the Greenland ice sheet. Science, 320(5877), 781-783 (doi: 10.1126/science.1153288)

Joughin I, Smith BE, Howat IM, Scambos T and Moon T (2010) Greenland flow variability from ice-sheet-wide velocity mapping. J. Glaciol., 56(197), 415-430 (doi: 10.3189/002214 310792447734)

Joughin I, Howat IM, Smith BE and Scambos T (2011) Measures greenland ice velocity: selected glacier site velocity maps from InSAR. NASA DAAC at the National Snow and Ice Data Center, Boulder, Colorado, USA (doi: 10.5067/MEASURES/ CRYOSPHERE/nsidc-0481.001)

Kamb B (1987) Glacier surge mechanism based on linked cavity configuration of the basal water conduit system. J. Geophys. Res., 92(B9), 9083-9100 (doi: 10.1029/JB092iB09p09083)

Kimura S, Holland PR, Jenkins A and Piggot M (2014) The effect of meltwater plumes on the melting of a vertical glacier face. J. Phys. Oceanogr., 44(12), 3099-3117 (doi: 10.1175/JPO-D-130219.1)

Kjeldsen KK and 5 others (2014) Ice-dammed lake drainage cools and raises surface salinities in a tidewater outlet glacier fjord, west Greenland. J. Geophys. Res.: Earth Surf., 119(6), 13101321 (doi: 10.1002/2013JF003034)

Langen PL and 13 others (2015) Quantifying energy and mass fluxes controlling godthabsfjord freshwater input in a $5-\mathrm{km}$ simulation (1991-2012). J. Clim., 28(9), 3694-3713 (doi: 10.1175/JCLI-D14-00271.1)

Lea JM and 7 others (2014) Fluctuations of a Greenlandic tidewater glacier driven by changes in atmospheric forcing: observations and modelling of kangiata nunaata sermia, 1859-present. Cryosphere, 8(6), 2031-2045 (doi: 10.5194/tc-8-2031-2014)

Lefebre F, Gallee H, van Ypersele JP and Greuell W (2003) Modeling of snow and ice melt at eth camp (west Greenland): a study of surface albedo. J. Geophys. Res., 108(D8) (doi: 10.1029/ 2001JD001160)

Marshall J, Adcroft A, Hill C, Perelman L and Heisey C (1997a) A finite-volume, incompressible Navier stokes model for studies of the ocean on parallel computers. J. Geophys. Res.: Oceans, 102(C3), 5753-5766 (doi: 10.1029/96JC02775)

Marshall J, Hill C, Perelman L and Adcroft A (1997b) Hydrostatic, quasi-hydrostatic, and nonhydrostatic ocean modeling. J. Geophys. Res.: Oceans, 102(C3), 5733-5752 (doi: 10.1029/ 96JC02776)

Meier M and 9 others (1994) Mechanical and hydrological basis for the rapid motion of a large tidewater glacier 1. Observations. J. Geophys. Res., 99(B8), 15219-15229 (doi: 10.1029/94JB00237)

Moon T, Joughin I, Smith B and Howat I (2012) 21st-century evolution of Greenland outlet glacier velocities. Science, 336(6081), 576-578 (doi: 10.1126/science.1219985)

Moon T and 6 others (2014) Distinct patterns of seasonal Greenland glacier velocity. Geophys. Res. Lett., 41(20), 7209-7216 (doi: 10.1002/2014GL061836)

Morlighem M, Rignot E, Mouginot J, Seroussi H and Larour E (2014) Deeply incised submarine glacial valleys beneath the Greenland ice sheet. Nat. Geosci., 7, 418-422 (doi: 10.1038/ngeo2167)

Morlighem M, Rignot E, Mouginot J, Seroussi H and Larour E (2015) lcebridge bedmachine greenland, version 2. NASA DAAC at the National Snow and Ice Data Center, Boulder, Colorado, USA (doi: 10.5067/AD7B0HQNSJ29)

Mortensen J, Lennert K, Bendtsen J and Rysgaard S (2011) Heat sources for glacial melt in a sub-arctic fjord (godthabsfjord) in contact with the Greenland ice sheet. J. Geophys. Res.: Oceans, 116(C1) (doi: 10.1029/2010JC006528)

Mortensen J and 6 others (2013) On the seasonal freshwater stratification in the proximity of fast-flowing tidewater outlet glaciers in a sub-arctic sill fjord. J. Geophys. Res.: Oceans, 118(3), 13821395 (doi: 10.1002/jgrc.20134)

Mortensen J, Bendtsen J and Lennert K and Rysgaard S (2014) Seasonal variability of the circulation system in a west Greenland tidewater outlet glacier fjord, godthabsfjord (64n). J. Geophys. Res.: Earth Surf., 119(12), 2591-2603 (doi: 10.1002/ 2014JF003267)

Morton B, Taylor G and Turner J (1956) Turbulent gravitational convection from maintained and instantaneous sources. Proc. R. Soc. Lond. Ser. A: Math. Phys. Sci., 234(1196), 1-23 (doi: 10.1098/rspa.1956.0011)

Motyka RJ, Hunter L, Echelmeyer KA and Connor C (2003) Submarine melting at the terminus of a temperate tidewater glacier, leconte glacier, Alaska, USA. Annals of Glaciology, 36 (1), 57-65 (doi: 10.3189/172756403781816374)

Motyka RJ, Dryer WP, Amundson J, Truffer M and Fahnestock M (2013) Rapid submarine melting driven by subglacial discharge, LeConte glacier, Alaska. Geophys. Res. Lett., 40(19), 5153-5158 (doi: 10.1002/grl.51011)

Pfeffer WT (2007) A simple mechanism for irreversible tidewater glacier retreat. J. Ceophys. Res., 112(F3) (doi: 10.1029/ 2006JF000590)

Pritchard HD, Arthern RJ, Vaughan DG and Edwards LA (2009) Extensive dynamic thinning on the margins of the Greenland and Antarctic ice sheets. Nature, 461(7266), 971-975 (doi: 10.1038/nature08471)

Rignot $\mathrm{E}$ and Kanagaratnam P (2006) Changes in the velocity structure of the Greenland ice sheet. Science, 311(5763), 986-990 (doi: 10.1126/science.1121381)

Rignot E, Fenty I, Xu Y, Cai C and Kemp C (2015) Undercutting of marine-terminating glaciers in west Greenland. Geophys. Res. Lett., 42(14), 5909-5917 (doi: 10.1002/2015GL064236)

Roeckner E and 13 others (2003) The atmospheric general circulation model echam5. Part 1: Model description. Max Planck Institute for Meteorology Report 349

Schild KM, Hawley RL and Morriss BF (2016) Subglacial hydrology at rink isbrae, west Greenland inferred from sediment plume appearance. Ann. Glaciol., 57, 118-127 (doi: 10.1017/aog.2016.1)

Schoof C (2010) Ice-sheet acceleration driven by melt supply variability. Nature, 468(7325), 803-806 (doi: 10.1038/nature09618)

Sciascia R, Straneo F, Cenedese C and Heimbach P (2013) Seasonal variability of submarine melt rate and circulation in an east 
Greenland fjord. J. Geophys. Res.: Oceans, 118(5), 2492-2506 (doi: 10.1002/jgrc.20142)

Shapero DN, Joughin IR, Poinar K, Morlighem $M$ and GilletChaulet F (2016) Basal resistance for three of the largest Greenland outlet glaciers. J. Geophys. Res.: Earth Surf., 121(1), 168-180

Shreve RL (1972) Movement of water in glaciers. J. Glaciol., 11(62), 205-214 (doi: 10.3198/1972JoG11-62-205-214)

Slater DA, Nienow PW, Cowton TR, Goldberg DN and Sole AJ (2015) Effect of near-terminus subglacial hydrology on tidewater glacier submarine melt rates. Geophys. Res. Lett., 42(8), 28612868 (doi: 10.1002/2014GL062494)

Slater DA, Goldberg DN, Nienow PW and Cowton TR (2016) Scalings for submarine melting at tidewater glaciers from buoyant plume theory. J. Phys. Oceanogr., 46(6), 1839-1855 (doi: 10.1175/JPO-D-15-0132.1)

Sole AJ and 6 others (2011) Seasonal speedup of a Greenland marine-terminating outlet glacier forced by surface melt induced changes in subglacial hydrology. J. Geophys. Res.: Earth Surf., 116(F3) (doi: 10.1029/2010JF001948)

Stevens LA and 5 others (2016) Linking glacially modified waters to catchment-scale subglacial discharge using autonomous underwater vehicle observations. Cryosphere, 10(1), 417-432 (doi: 10.5194/tc-10-417-2016)

Straneo F and Cenedese C (2015) The dynamics of Greenland's glacial fjords and their role in climate. Annu. Rev. Mar. Sci., 7 (1), 89-112 (doi: 10.1146/annurev-marine-010213-135133)

Straneo F and Heimbach P (2013) North Atlantic warming and the retreat of Greenland's outlet glaciers. Nature, 504, 36-43 (doi: 10.1038 /nature12854)

Straneo F and 7 others (2010) Rapid circulation of warm subtropical waters in a major glacial fjord in east Greenland. Nat. Geosci., 3 (3), 182-186 (doi: 10.1038/ngeo764)
Sugiyama S and 7 others (2011) Ice speed of a calving glacier modulated by small fluctuations in basal water pressure. Nat. Geosci., 5, 597-600 (doi: 10.1038/ngeo1218)

Tedstone AJ and Arnold NS (2012) Automated remote sensing of sediment plumes for identification of runoff from the Greenland ice sheet. J. Glaciol., 58(210), 699-712 (doi: 10.3189/2012JoG11J204)

Thomas R, Frederick E, Krabill W, Manizade S and Martin C (2009) Recent changes on Greenland outlet glaciers. J. Glaciol., 55(189), 147-162 (doi: 10.3189/002214309788608958)

Turner JS (1973) Buoyancy effects in fluids. Cambridge University Press

van den Broeke $M$ and 8 others (2009) Partitioning recent Greenland mass loss. Science, 326(5955), 984-986 (doi: 10.1126/science. 1178176)

Vieli A, Jania J, Blatter $\mathrm{H}$ and Funk M (2004) Short-term velocity variations on hansbreen, a tidewater glacier in spitsbergen. J. Glaciol., 50(170), 389-398 (doi: 10.3189/172756504781829963)

Walder JS and Fowler A (1994) Channelized subglacial drainage over a deformable bed. J. Glaciol., 40(134), 3-15 (doi: 10.3198/1994JoG40-134-3-15)

Walter F, Chaput J and Luthi MP (2014) Thick sediments beneath Greenland's ablation zone and their potential role in future ice sheet dynamics. Geology, 42(6), 487-490 (doi: 10.1130/ G35492.1)

Xu Y, Rignot E, Fenty I, Menemenlis D and Flexas MM (2013) Subaqueous melting of store glacier, west Greenland from three-dimensional, high-resolution numerical modeling and ocean observations. Geophys. Res. Lett., 40(17), 4648-4653 (doi: 10.1002/grl.50825)

Zuo Z and Oerlemans J (1996) Modelling albedo and specific mass balance of the Greenland ice sheet: calculations for the sondre stromfjord transect. J. Glaciol., 42(141), 305-317 (doi: 10.3198/ 1996JoG42-141-305-317)

MS received 1 August 2016 and accepted in revised form 8 December 2016; first published online 19 January 2017 